\title{
Bilateral cryptorchidism with bilateral synchronous abdominal testicular germ cell tumour
}

\author{
Venkatesh Seetharam, ${ }^{1}$ Zeeshan BM Hameed, ${ }^{1}$ Shaila Bhat Talengala, ${ }^{2}$ \\ Joseph Thomas ${ }^{1}$
}

\begin{abstract}
${ }^{1}$ Department of Urology, Kasturba Medical College, Manipal University, Manipal, Karnataka, India

${ }^{2}$ Department of Pathology, Melaka Manipal Medical College, Manipal, Karnataka, India
\end{abstract}

Correspondence to Dr Zeeshan BM Hameed, zeeshanhameedbm@gmail.com

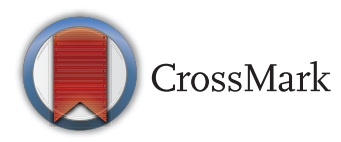

To cite: Seetharam $V$, Hameed ZBM, Talengala SB, et al. BMJ Case Rep Published online: [please include Day Month Year] doi:10.1136/bcr-2013203085

\section{SUMMARY}

Cryptorchidism or undescended testis is a very common anomaly of the male genitourinary system. It is one of the established risk factors for testicular tumour. The commonest malignancy noted in cryptorchidism is seminoma testis. The presence of bilateral abdominal synchronous testicular tumour in cryptorchidism is very rare.

\section{BACKGROUND}

Testicular tumour is the most common malignancy among men aged $20-40$ years. The most common variant of testicular tumour is the germ cell tumours (GCTs). The incidence of bilateral GCT is approximately $2 \%$. Men with cryptorchidism are 4-6 times more likely to be diagnosed with testicular cancer. ${ }^{1}$ The presence of bilateral synchronous abdominal tumour in bilateral cryptorchid testis has been reported only twice. This is the third case of bilateral synchronous GCT reported in English literature. $^{23}$

\section{CASE PRESENTATION}

A 28-year-old man presented with dull aching chronic lower abdominal pain. He also had abdominal distension and bloating sensation for the past 2 months. He was heterosexual and had not fathered any children. He gave a history of absence of both the testes in the scrotum since birth. There was no history of loss of weight, appetite or any surgery in the past. He was well built and had attained secondary sexual characters. On examination of the abdomen, there were two palpable well-defined masses in the lower abdomen, measuring around $8 \times 8$ and $10 \times 8 \mathrm{~cm}$. The larger one occupied the left lumbar, umbilical and hypogastric region. The other mass was in the right lumbar and iliac fossa. Both the masses were non-tender, had smooth surface with well-defined margins and restricted mobility. The mass lesions did not move with respiration and were dull on percussion. The scrotum was empty and underdeveloped.

\section{INVESTIGATIONS}

Routine blood investigations were normal. The serum $\alpha$ fetoprotein (AFP) and $\beta$ human chorionic gonadotropin (HCG) levels were normal. Serum lactate dehydrogenase (LDH) was elevated to $2890 \mathrm{U} / \mathrm{L}$. Ultrasonography (USG) of the abdomen and pelvis reported two large homogeneous echo texture mass lesions in the bilateral lumbar region with the absence of testes in the scrotum (figure $1 \mathrm{~A}$ ). The chest X-ray was normal (figure 1B). Contrast-enhanced CT (CECT) of the abdomen and pelvis showed two welldefined homogenously dense mass in the lower abdomen measuring $13.4 \times 12.2 \mathrm{~cm}$ on the left side and $9.6 \times 7.8 \mathrm{~cm}$ on the right side, without any calcification and empty scrotum. There was no evidence of any lymphadenopathy in the retroperitoneum. Both kidneys were normally functioning and there was no evidence of ureteric obstruction. Features were suggestive of intra-abdominal testes with malignant transformation (figure $2 \mathrm{~A}, \mathrm{~B}$ ).

\section{DIFFERENTIAL DIAGNOSIS}

Bilateral undescended testis (UDT) with abdominal testicular tumour.

\section{TREATMENT}

The patient underwent laparotomy, which showed two well-defined mass lesions in the retroperitoneum without any adhesions/infiltration to the surrounding structures; there were no lymph nodes. Complete excision of the tumour was carried out. Histopathology examination revealed bilateral seminoma testes (figure $3 \mathrm{~A}, \mathrm{~B}$ ). The patient received four cycles of chemotherapy-BEP (bleomycin, etoposide and cisplatin) regimen.

\section{OUTCOME AND FOLLOW-UP}

The patient recovered well and is on regular follow-up.

\section{DISCUSSION}

Testicular tumours are more commonly seen in young adults. The most common variants are GCTs, in which seminoma accounts for 52-56\%. The incidence of bilateral GCT is approximately $2 \%$. The risk factors for testicular cancer are mainly cryptorchidism, a family history of testicular cancer, a personal history of testicular cancer and intratubular germ cell neoplasia. ${ }^{1}$ Around $80-85 \%$ of bilateral testicular tumours are metachronous and $15-20 \%$ are synchronous. However, the occurrence of synchronous tumour in cryptorchidism is extremely rare. There are only two cases of synchronous abdominal tumour in bilateral cryptorchidism reported (table 1). ${ }^{2}{ }^{3}$ The case reported here has larger bilateral abdominal lesions much larger in dimension than the previous reported cases.

Cryptorchidism or UDT is characterised by the failure of descent of testis in the scrotum. It is more commonly seen in premature male neonates, with the incidence around 1-4\% of full term and 
Figure 1 (A) Ultrasonogram showing two large homogeneous echo texture mass lesions in the bilateral lumbar region. (B) Chest X-ray showing normal lung fields.

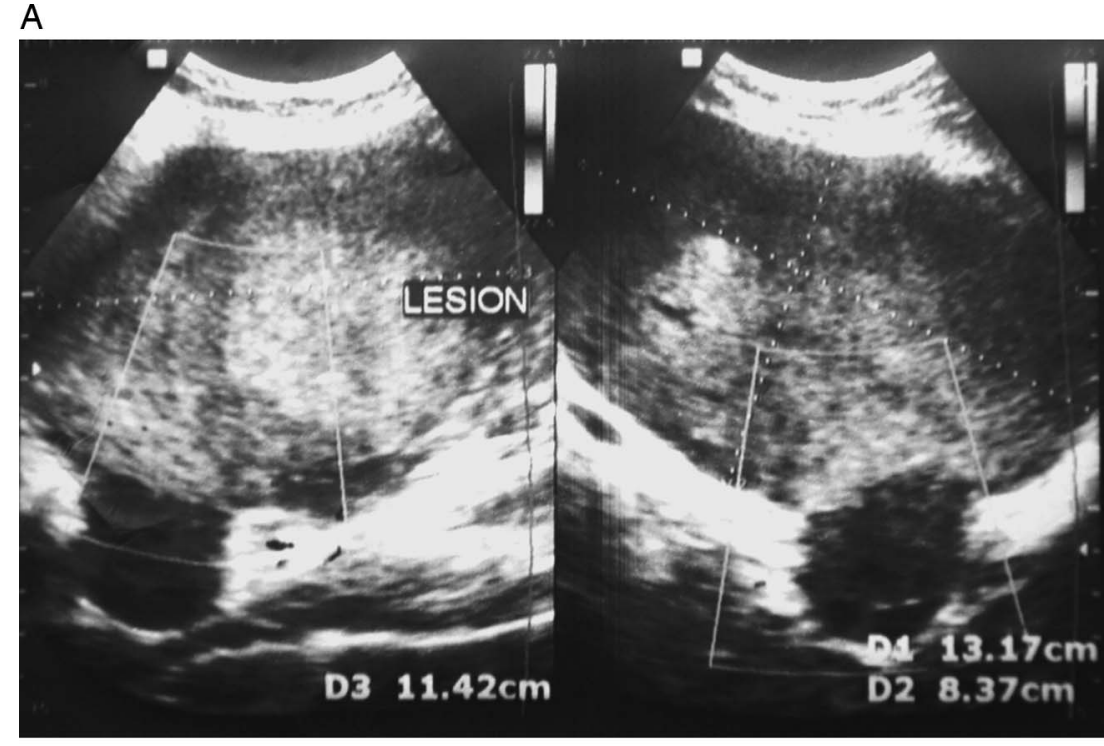

B

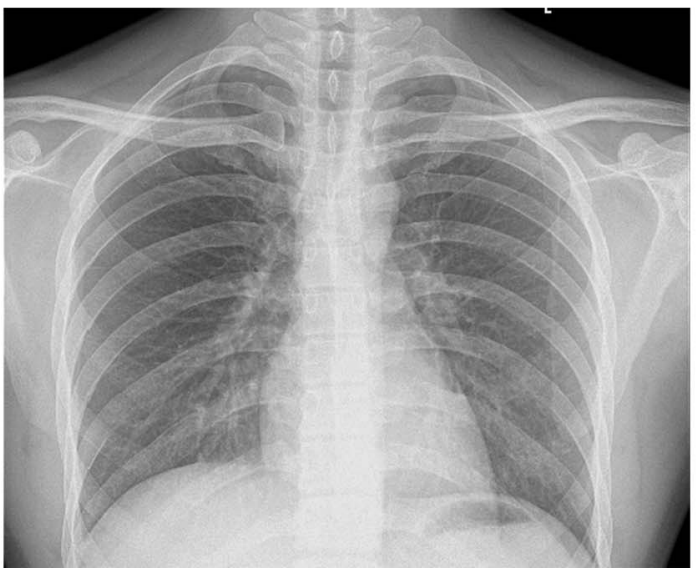

$1-45 \%$ of preterm male neonates. ${ }^{4}$ The pathogenesis of cryptorchidism remains largely unknown, but is most likely multifactorial, involving genetic and environmental risk factors. Spontaneous descent occurs by 6 months of age in $66 \%$ of infants. Cryptorchidism is associated with syndromes such as Down, Klinefelter and prune-belly. It is also seen in conditions such as posterior urethral valve, abdominal wall defects- omphalocele and gastroschisis, and neural tube defects-myelomeningocele, spigelian hernia and cerebral palsy.

There is a 4-6 times increased risk of cancer in the UDT. The contralateral descended testis in a cryptorchid male also has a slightly increased risk of developing malignancy. The mechanism behind the increased risk of malignancy in cryptorchidism is due to the abnormal environment with a high temperature in
A

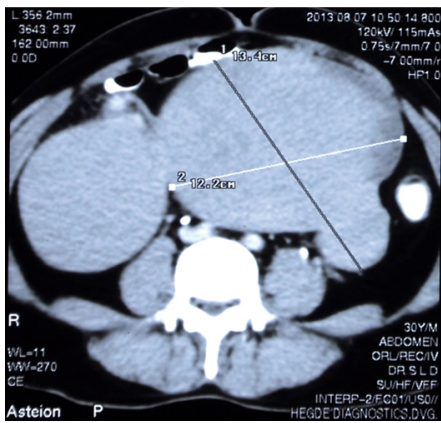

B

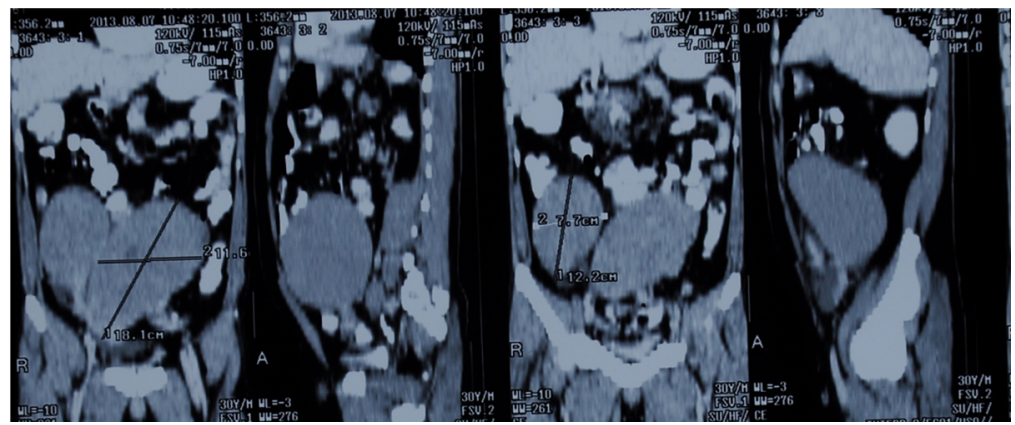

Figure 2 (A) Contrast-enhanced CT (CECT) of the abdomen axial view showing a homogenously dense mass measuring $9.6 \times 7.8 \mathrm{~cm}$ in the lumbar region on the right side and a large tumour measuring $13.4 \times 12.2 \mathrm{~cm}$ on the left side. (B) CECT coronal and sagittal view showing bilateral tumours in the abdominal undescended testis. 


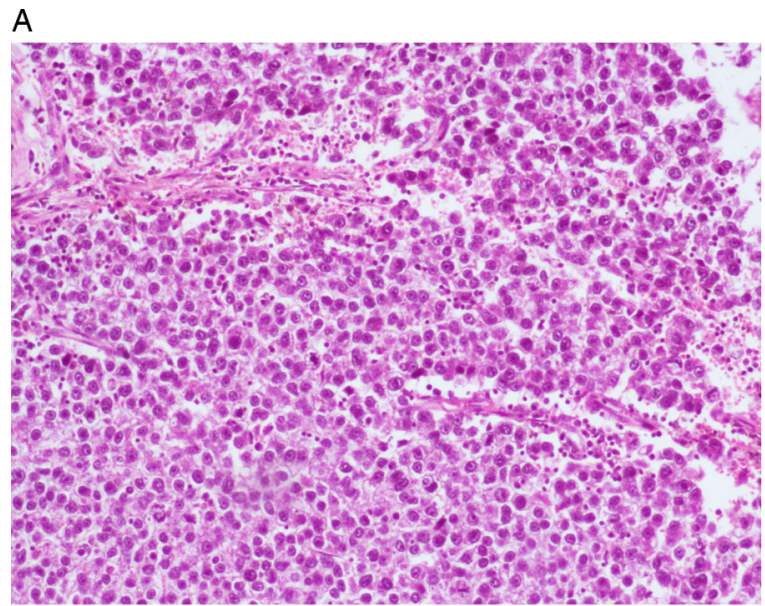

B

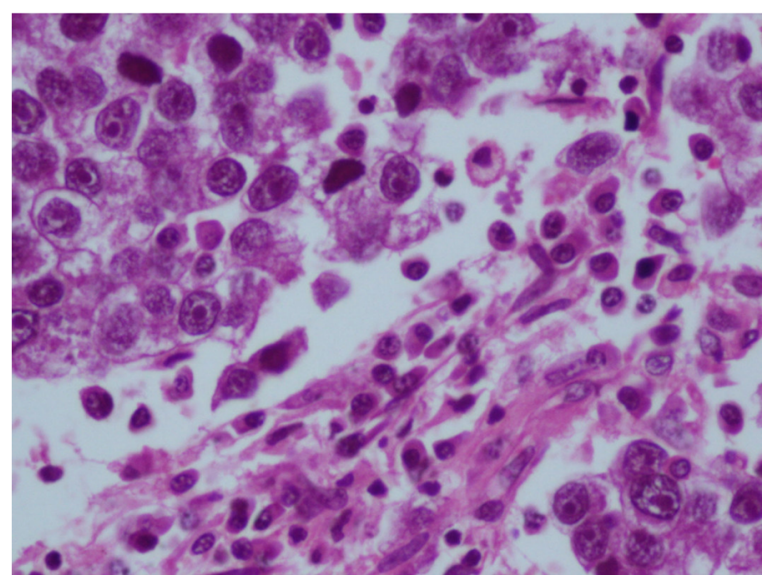

Figure 3 (A) Photomicrograph of seminoma testes showing sheets of malignant germ cells intersected by fibrous septae with a lymphocytic infiltrate $(\mathrm{H} \& \mathrm{E} \times 40)$. (B) Photomicrograph showing a tumour composed of large polygonal cells with distinct borders and pale nuclei with prominent nucleoli and a sparse lymphocytic infiltrate (H\&Ex400).

UDT, which prevents the transformation of gonocytes into stem cells and also arrests subsequent apoptosis. These abnormal gonocytes get accumulated within the seminiferous cords, and undergo mutations. Over a period of time they become the source of carcinoma in situ cells and develop into tumours. ${ }^{5}$ The overall risk of GCT in a cryptorchid testis reduces if orchidopexy is carried out before puberty. The risk of malignancy in UDT reduces after orchidopexy, as the testis is relocated into the scrotum which is a low temperature area, hence promoting normal germ cell development and thereby reducing the probability of low sperm count and malignancy. ${ }^{6}$

The diagnosis of malignancy in UDT is made on the basis of clinical suspicion, radiological imaging and histopathological examination. The management is similar to the testicular tumours in the normally descended testis. The serum markers AFP, $\beta$ HCG and LDH may be elevated. ${ }^{7}$ Imaging with USG, CECT of the abdomen and pelvis may reveal a large intra-abdominal mass lesion with or without necrosis and calcification. Imaging studies also help in locating the contralateral UDT. Chest X-ray is carried out to look for lung metastasis. In seminoma, the thoracic metastasis in the absence of retroperitoneal disease or elevated serum tumour markers is uncommon. According to Horan $e t a l^{8}$, the routine chest CT may be associated with a high rate of false-positive findings, which may complicate subsequent therapy. CT of the thorax should be performed in patients with elevated postorchiectomy levels of serum tumour markers, evidence of metastatic disease by physical examination or abdominopelvic CT or abnormal or equivocal findings on chest radiography. The most common histopathological variant of tumour in UDT is seminoma followed by embryonal carcinoma, teratoma and choriocarcinoma.

The treatment of choice for synchronous bilateral testicular tumour is bilateral high inguinal orchiectomy. The role of CT-guided/USG-guided biopsy from the testicular tumour is confined to patients with a suspicion of lymphoma or metastasis in the testis. ${ }^{1}$ Testis sparing surgery is carried out in small tumours less than $2 \mathrm{~cm}$, to avoid the sequelae of castration which include infertility, dependence on androgen replacement therapy. ${ }^{9}$ Depending on the stage of the disease, histopathology and the serum markers, the adjuvant chemotherapy is given. Hormone replacement therapy in the form of testosterone is essential postoperatively. A thorough counselling of the patient regarding the risk of recurrence, infertility and surveillance is necessary.

\section{Learning points}

- Cryptorchidism is the most common congenital genitourinary anomaly.

- The most common testicular tumour in cryptorchidism is seminoma testis.

- In a patient with abdominal mass and undescended testis, malignancy should be suspected.

Table 1 Comparison between the patients with synchronous testicular tumour in undescended testis

\begin{tabular}{|c|c|c|c|c|c|c|c|}
\hline Author & $\begin{array}{l}\text { Age } \\
\text { (years) }\end{array}$ & Presentation & Stage & $\begin{array}{l}\text { Tumour } \\
\text { markers }\end{array}$ & Surgery & Histology & Follow-up \\
\hline Kumar et al & 30 & $\begin{array}{l}\text { Flank pain } \\
\text { Infertility }\end{array}$ & $\mathrm{T}_{1} \mathrm{~N}_{0} \mathrm{M}_{0}$ & $\begin{array}{l}\text { LDH-1257 } \\
\text { AFP- } 2.02 \\
\beta H C G-0.38\end{array}$ & $\begin{array}{l}\text { Laparotomy and } \\
\text { complete excision }\end{array}$ & $\begin{array}{l}\text { Seminoma poorly } \\
\text { differentiated }\end{array}$ & $\begin{array}{l}4 \text { cycles BEP } \\
\text { No recurrence in } \\
8 \text { months }\end{array}$ \\
\hline $\begin{array}{l}\text { Agarwal } \\
\text { et al }\end{array}$ & 23 & $\begin{array}{l}\text { Heaviness in abdomen, low } \\
\text { backache, constipation }\end{array}$ & $\mathrm{T}_{1} \mathrm{~N}_{0} \mathrm{M}_{0}$ & $\begin{array}{l}\text { LDH- N } \\
\text { AFP- N } \\
\text { BHCG- N }\end{array}$ & $\begin{array}{l}\text { Laparotomy and } \\
\text { complete excision }\end{array}$ & Pure seminoma & $\begin{array}{l}4 \text { cycles BEP } \\
\text { No recurrence in } \\
60 \text { months }\end{array}$ \\
\hline $\begin{array}{l}\text { Hameed } \\
\text { et al }\end{array}$ & 28 & $\begin{array}{l}\text { Lower abdominal pain, abdominal } \\
\text { distension }\end{array}$ & $\mathrm{T}_{1} \mathrm{~N}_{0} \mathrm{M}_{0}$ & $\begin{array}{l}\text { LDH-2890 } \\
\text { AFP-1.64 } \\
\beta H C G-0.21\end{array}$ & $\begin{array}{l}\text { Laparotomy and } \\
\text { complete excision }\end{array}$ & Pure seminoma & $\begin{array}{l}4 \text { cycles BEP } \\
\text { No recurrence in } \\
6 \text { months }\end{array}$ \\
\hline
\end{tabular}

AFP, $\alpha$ fetoprotein $(\mathrm{ng} / \mathrm{mL}) ; B E P$, bleomycin, etoposide and cisplatin; $\beta H C G, \beta$ human chorionic gonadotropin $(\mathrm{mlU} / \mathrm{mL}) ; \mathrm{LDH}$, lactate dehydrogenase $(\mathrm{U} / \mathrm{L}) ; \mathrm{N}, \mathrm{normal} ; \mathrm{T}_{1} \mathrm{~N}_{0} \mathrm{M}_{0}$, tumour node, metastasis. 
Contributors All the authors have equally contributed in the data collection, drafting of the case report, and revised it critically for important intellectual content and final approval.

\section{Competing interests None.}

Patient consent Obtained.

Provenance and peer review Not commissioned; externally peer reviewed.

\section{REFERENCES}

1 Andrew JS, Timothy DG. Neoplasms of the testis. In: Alan J. ed Wein: Campbell-Walsh urology book. 10th edn. Philadelphia: WB Saunders, 2012:837-70.

2 Kumar P, Kumar R, Tiwary SK, et al. Bilateral synchronous testicular germ cell tumours in a patient with bilateral cryptorchidism. S Afr J Surg 2012;50:96-7.
3 Agrawal S, Bajpai R, Agrawal RK, et al. Bilateral synchronous seminoma with bilateral cryptorchidism of the testis. Indian I Urol 2010;26:587-9.

4 Docimo SG. The results of surgical therapy for cryptorchidism: a literature review and analysis. J Urol 1995;154:1148-52.

5 Ong C, Hasthorpe S, Hutson JM. Germ cell development in the descended and cryptorchid testis and the effects of hormonal manipulation. Pediatr Surg Int 2005;21:240-54.

6 John MH, Adam B, Tamara N. Cryptorchidism. Semin Pediatr Surg 2010;19:215-24.

7 Coogan CL, Foster RS, Simmons GR, et al. Bilateral testicular tumors, management and outcome in 21 patients. Cancer 1998;83:547-52.

8 Horan G, Rafique A, Robson J, et al. CT of the chest can hinder the management of seminoma of the testis; it detects irrelevant abnormalities. $\mathrm{Br} J$ Cancer 2007:96:882-5.

9 Matthew JR, Daniel C, Benjamin MB, et al. A case of synchronous bilateral testicular seminoma. Nat Clin Pract Urol 2008;7:397-491.

Copyright 2014 BMJ Publishing Group. All rights reserved. For permission to reuse any of this content visit http://group.bmj.com/group/rights-licensing/permissions.

BMJ Case Report Fellows may re-use this article for personal use and teaching without any further permission.

Become a Fellow of BMJ Case Reports today and you can:

- Submit as many cases as you like

- Enjoy fast sympathetic peer review and rapid publication of accepted articles

- Access all the published articles

- Re-use any of the published material for personal use and teaching without further permission

For information on Institutional Fellowships contact consortiasales@bmjgroup.com

Visit casereports.bmj.com for more articles like this and to become a Fellow 